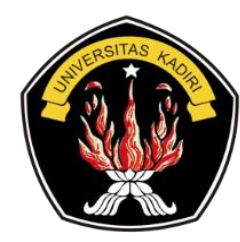

Tersedia secara online di http://ojs.unik-kediri.ac.id/index.php/jatiunik/issue/view/76

\title{
Analisis Risiko Keselamatan Dan Kesehatan Kerja Menggunakan Metode HAZOP's Di Area Gas Cleaning System Di PT. RK
}

\author{
Muhammad Bob Anthony ${ }^{* 1}$ \\ ${ }^{1}$ Program Studi Teknik Industri, Fakultas Teknik, Universitas Serang Raya \\ Email : tonypbmti@gmail.com ${ }^{1}$
}

\section{Informasi Artikel}

Riwayat Artikel :

Received : 3 - Septermber -2019

Revised : 19 - Oktober - 2019

Accepted : 24 - Oktober - 2019

\section{Kata kunci :}

HAZOP

Gas Cleaning System

Potential of Hazard

Risk Levels

Untuk melakukan sitasi pada penelitian ini dengan format :

S. Ramli, Pedoman Praktis Manajemen Risiko dalam Prespektif K3 OHS Risk Management. Jakarta: Dian Rkyat, 2010.

\section{A b stract}

PT. RK is one of the major international steel producing companies. This study aims to determine the potential hazards and the value of the level of risk that is likely to occur in the new plant owned by PT. RK i.e. the gas cleaning system area which is currently in the process of entering $95 \%$ progress. This study uses the Hazard \& Operability Study (HAZOPs) method in analyzing risks in the gas cleaning system area of PT. RK. The Hazard \& Operability Study (HAZOPs) method was used in this study because this method is very suitable for a new plant to be used. Based on the identification of potential hazards and risk analysis that has been done in the area of gas cleaning system using the HAZOPs method, it was found that 11 deviations that might occur from all existing nodes, i.e. for extreme risk levels of 1 (one) deviation or $9 \%$, level high risk of 2 (two) deviations or 18\%, moderate risk level of 6 (six) deviations or $55 \%$ and low risk level of 2 (two) deviations or $18 \%$.

\section{A b s t r a k}

PT. RK merupakan salah satu perusahaan manufaktur besar penghasil baja berskala internasional. Penelitian ini bertujuan untuk mengetahui potensi bahaya dan nilai level risiko yang kemungkinan terjadi di plant baru milik PT. RK yaitu area gas cleaning system yang saat ini proses pekerjaannya sudah memasuki progress $95 \%$. Penelitian ini menggunakan metode Hazard \& Operability Study (HAZOPs) dalam menganalisa risiko di area gas cleaning system PT. RK. Metode Hazard \& Operability Study (HAZOPs) digunakan dalam penelitian ini dikarenakan metode ini sangat cocok untuk sebuah plant baru yang akan digunakan. Berdasarkan identifikasi potensi bahaya dan analisa risiko yang telah dilakukan di area gas cleaning system dengan menggunakan metode HAZOPs, didapatkan bahwa 11 penyimpangan yang kemungkinan terjadi dari semua node yang ada yaitu untuk level risiko extreme sebanyak 1 (satu) penyimpangan atau sebesar 9\%, level risiko high risk sebanyak 2 (dua) penyimpangan atau sebesar $18 \%$, level risiko moderate sebanyak 6 (enam) penyimpangan atau sebesar 55\% dan level 


\section{Pendahuluan}

Sumber daya manusia memiliki karakter yang berbeda-beda didalam melakukan pekerjaannya. Setiap tempat kerja yang digunakan untuk bekerja dipastikan memiliki sumber yang berpotensi menyebabkan kerugian bagi sumber daya manusia yang berada pada lokasi sumber kerusakan. Kerugian yang ditanggung adalah risiko kecelakaan kerja. Risiko tersebut memiliki dampak-dampak ringan, sedang dan berat [1], [2]. Kerugian yang dialami adalah menyangkut kesehatan sumber daya manusianya. Di Indonesia kerugiankerugian tersebut dinamakan kecelakaan kerja. Kecelakaan kerja adalah peristiwa yang tidak diharapkan oleh sumber daya manusia, yang tidak sengaja terjadi dan tidak dapat diduga. Akibat adanya kecelakaan kerja diakibatkan beberapa faktor yaitu peristiwa kecelakaan kerja, adanya penyakit kerja dan penyakit lingkungan kerja. Pelaksanaan penerapan keselamatan dan kesehatan kerja pada perusahaan belum tentu dilaksanakan secara menyeluruh. Dalam Undang - Undang yang mengatur ini sebenarnya sudah ada, hanya saja belum diterapkan sepenuhnya oleh perusahaan. PT. RK merupakan salah satu perusahaan manufaktur baja besar berskala internasional yang beroperasi sejak tahun 1970 . Seiring dengan berkembangnya waktu, biaya produksi pada bagian hilir PT. RK cenderung mengalami kenaikan pada penggunaan gas alam, energi listrik dan bahan baku utama. Penggunaan energi listrik disebuah perusahaan sangat besar, biaya yang dihabiskan dalam satu bulan pun akan memberikan pengaruh kepada perusahaan jika terjadi kenaikan tarif penggunaan energi listrik. Selain itu, gas alam pun juga mengalami kenaikan harga. Perusahaan perlu memiliki energi alternatif agar mampu mengoperasikan proses manufaktur pada perusahaan. Proses manufaktur tetap berjalan dengan biaya yang mampu ditekan agar profit perusahaan mampu ditingkatkan. Keadaan yang dapat menyebabkan kecelakaan pada pekerja akan ditanggung perusahaan serta diberikan suatu kompensasi sebagai ganti rugi atas kecelakaan yang terjadi [3]. Untuk mengurangi hal ini, sejak tahun 2012 PT. RK melakukan pembangunan sebuah plant baru yang di dalamnya terdapat gas cleaning system dan saat ini pekerjaan proyek plant tersebut telah mencapai kemajuan dengan persentase sebesar 95\%. Mengingat kondisi gas cleaning system yang masih dalam proses pembangunan dan jumlah karyawan yang banyak perlu dilakukan kewajiban bagi perusahaan dalam menerapkan K3 (Keselematan dan Kesehatan Kerja) [4],[5],[6]. Dalam proses identifikasi bahaya dan analisa risiko sebelum karyawan bekerja mengoperasikan di area gas cleaning system ini. Area gas cleaning system memiliki fungsi utama yaitu untuk mengurangi kadar debu dan menurunkan suhu gas keluaran dari dalam furnace saat melakukan peleburan hot metal. Tujuan penelitian ini adalah untuk mengetahui potensi bahaya dan nilai level risiko yang terjadi di area gas cleaning system sebelum dioperasikan serta memberikan rekomendasi pencegahan dan penanganan yang bisa dilakukan dalam menangani potensi bahaya di area gas cleaning system tersebut [7], [8].

\section{Tinjauan Pustaka}

Kesehatan kerja adalah promosi dan pemeliharaan dari derajat kesehatan yang terdiri dari kesehatan fisik, mental dan sosial dari tenaga kerja dalam semua pekerjaannya melalui pencegahan penyakit, pengontrolan risiko $\mathrm{K} 3$, penyesuaian pekerjaan terhadap tenaga kerja dan adaptasi tenaga kerja terhadap pekerjaan (Ramdan, 2006). Kecelakaan kerja merupakan kecelakaan yang terjadi berhubungan dengan kerja, termasuk penyakit yang timbul karena hubungan kerja, demikian pulakecelakaan yang terjadi dalam perjalanan ke dan dari tempat kerja. Hazard atau bahaya dapat didefinisikan sebagai keadaan yang menimbulkan atau 
meningkatkan terjadinya chance of loss (kemungkinan kerugian) dari suatu bencana tertentu. Jadi, hal-hal seperti kecerobohan pemeliharaan rumah yang buruk, jalan raya jelek, mesin yang tidak terpelihara, dan pekerjaan yang berbahaya adalah hazard dan keadaan tersebut yang meningkatkan kemungkinan kerugian (Darmawi, 2016). The Hazard and Operability Study (HAZOP) adalah standar teknik analisis bahaya yang digunakan dalam persiapan penetapan keamanan dalam suatu sistem atau modifikasi untuk suatu keberadaan potensi bahaya atau masalah operability nya. HAZOP adalah suatu metode identifikasi bahaya yang sistematis teliti dan terstruktur untuk mengidentifikasi berbagai permasalahan yang menganggu jalanya proses dan risiko yang terdapat pada suatu peralatan yang dapat menimbulkan risiko merugikan bagi manusia/ fasilitas pada sistem. Dengan kata lain metode ini digunakan sebagai upaya pencegahan sehingga proses yang berlangsung dalam suatu sistem dapat berjalan lancar dan aman (Juliana, 2008). Dasar penilaian risiko dan pengendaliannya (risk assessment and control) dalam prosedur yang ditetapkan oleh UNSW adalah sebagai berikut:
a. Identifikasi aktivitas.
b. Identifikasi siapa yang mungkin akan terkena risiko pada aktivitas tertentu.
c. Identifikasi bahaya.
d. Identifikasi risiko yang terkait.
e. Memberi nilai pada risiko dengan control yang ada.
f. Mengidentifikasi control tambahan yang sesuai.
g. Menilai ulang risiko.
h. Membuat semua daftar prosedur keadaan darurat yang berhubungan dengan aktivitas tertentu.
i. Melaksanakan pengendalian risiko.
j. Membuat daftar dokumen legislative yang terkait dengan penilaian risiko.
k. Otorisasi penilaian risiko.
1. Menandatangani penilaian risiko.
m. Mengamati kontrol yang telah dilakukan

\section{Metode Penelitian}

Penelitian ini dilakukan di PT. RK yang bergerak dibidang industri manufaktur baja berskala internasional. Objek penelitian ini adalah area gas cleaning system di PT. RK. Pengumpulan data dilakukan dengan tiga cara yaitu :

1. Observasi adalah melakukan kegiatan untuk meninjau aktifitas ditempat penelitian dilaksanakan. Didalam observasi pada penelitian ini yaitu melakukan observasi pada aktivitas kerja di area gas cleaning system.

2. studi literatur merupakan rangakaian dari kegiatan untuk mengumpulkan data - data terkait dengan pustaka melakukan pencatatam dan mengelola bahan - bahan yang digunakan pada penelitian.

3. Survei langsung ke lapangan melalui wawancara kepada pihak manajemen perusahaan dan beberapa pekerja PT. RK selama enam bulan yaitu bulan juli sampai dengan desember 2018. 


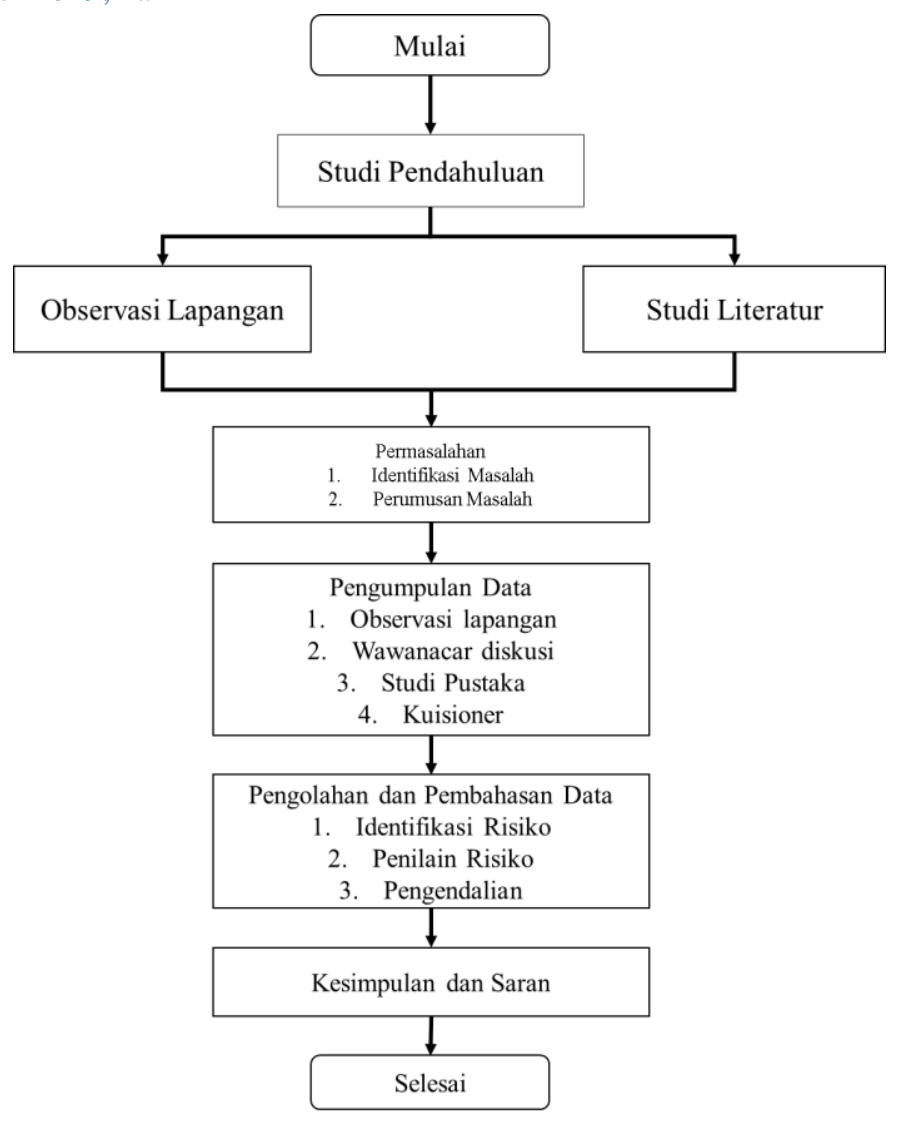

Gambar 1 Diagram Alir Penelitian

HAZOPs (Hazard and Operability Study) adalah teknik identifikasi bahaya yang digunakan untuk industri proses seperti industri kimia, petrokimia dan kilang minyak serta digunakan pada lingkup kerja yang memiliki risiko - risiko kerja berbahaya [6], [9]. Setiap industri proses pasti memiliki berbagai parameter operasi seperti suhu, tekanan, aliran, campuran dan level. Bahaya dalam industri proses dapat terjadi karena adanya penyimpangan dari parameter operasi melewati batas toleransinya. Tekanan yang meningkat melampaui daya tahan bejana dapat mengakibatkan peledakan. Aliran yang terhambat karena buntu dapat menyebabkan gangguan operasi serius [10]. Risiko diidentifikasi sebagai hasil dari frekuensi dimana suatu event diprediksi untuk muncul dan hasil akhir dari event tersebut yang dimana analisis dari risiko ini dievaluasi oleh HAZOPs dengan sangat detail [11]. Teknik HAZOPs biasanya menggunakan pendekatan dengan kata penunjuk (guideword) dan dapat juga menggunakan gabungan guideword dengan parameter [1], [10]. Keistimewaan yang penting dari HAZOPs yaitu digunakannya team dan narasumber. Team adalah gabungan dari beberapa personil dengan pengalaman dan pengetahuan yang cukup yang melakukan studi tentang kecelakaan kerja [12], [13], [4], [12], [14].

Tabel 1. Kata Panduan dalam melakukan HAZOPs

\begin{tabular}{|l|l|}
\hline Guide Word & \multicolumn{1}{|c|}{ Arti } \\
\hline No & Tidak ada tujuan perancangan yang tercapai \\
\hline More & Peningkatan kuantitatif pada parameter \\
\hline Less & Penurunan kuantitatif pada pada parameter \\
\hline Part of & $\begin{array}{l}\text { Hanya beberapa tujuan perancangan yang } \\
\text { tercapai }\end{array}$ \\
\hline As well as & Tambahan aktivitas/ kegiatan yang terjadi \\
\hline Other than & Penggantian lengkap kegiatan lain terjadi \\
\hline
\end{tabular}

(Sumber :[15], [16], [17]) 
Didalam melakukan studi tentang HAZOPs, informasi-informasi di bawah ini sangat dibutuhkan yaitu :

1. Diagram aliran proses atau process flow diagrams (PFD)

2. Diagram pipa dan instrumentasi atau piping and instrumentation diagrams (P\&IDs) [6]. Pada diagram pipa digunakan untuk melakukan analisa tentang kerusakan - kerusakan serta potensi adanya bahaya [14].

3. Diagram area atau layout diagrams

4. Keseimbangan material dan panas atau heat and material balances [9], [18]. Keseimbangan digunakan untuk menganalisa apakah material memiliki temperatur panas yang mampu disesuaikan dengan keadaan dilingkungan kerja.

5. Lembar data keselamatan material atau material safety data sheets

6. Instruksi kerja operasional

7. Lembar data peralatan dan prosedur emergency jika ada

Untuk menghitung besarnya nilai level risiko yang dihasilkan dari sumber bahaya dapat diperoleh dengan menghitung nilai Risk Rating Number (RRN). Perhitungan Risk Rating Number (RRN) dengan formula sebagai berikut [19], [20],[21], [22]:

$$
\text { Risk Rating Number }(R R N)=L \times C \text {. }
$$

Keterangan:

$\mathrm{L}=$ Likelihood of occurrence (kemungkinan frekuensi kejadian)

$\mathrm{C}=$ Consequences $($ tingkat keparahan)

Untuk mengetahui dari kriteria Likelihood of occurrence (kemungkinan frekuensi kejadian), Consequences (tingkat keparahan) dan Risk Rating Number (RRN) pada tabel berikut :

Tabel 2 Kriteria Likelihood

\begin{tabular}{|c|c|c|c|}
\hline \multirow[t]{2}{*}{ Level } & \multirow[t]{2}{*}{ Kriteria } & \multicolumn{2}{|c|}{ Deskripsi } \\
\hline & & Kualitatif & Kuantitatif \\
\hline 1 & Jarang terjadi & $\begin{array}{l}\text { Dapat dipikirkan tetapi tidak } \\
\text { hanya saat keadaan yang } \\
\text { ekstrim }\end{array}$ & $\begin{array}{l}\text { Kurang dari } 1 \text { kali per } 10 \\
\text { tahun }\end{array}$ \\
\hline 2 & $\begin{array}{l}\text { Kemungkinan } \\
\text { kecil }\end{array}$ & $\begin{array}{l}\text { Belum terjadi tetapi bisa } \\
\text { muncul/ terjadi pada suatu } \\
\text { waktu }\end{array}$ & Terjadi 1 kali per 10 tahun \\
\hline 3 & Mungkin & $\begin{array}{l}\text { Seharusnya terjadi dan } \\
\text { mungkin telah terjadi/ muncul } \\
\text { disini atau ditempat lain }\end{array}$ & $\begin{array}{l}1 \text { kali per } 5 \text { tahun sampai } \\
\text { dengan } 1 \text { kali per tahun }\end{array}$ \\
\hline 4 & $\begin{array}{l}\text { Kemungkinan } \\
\text { besar }\end{array}$ & $\begin{array}{l}\text { Dapat terjadi dengan mudah, } \\
\text { mungkin muncul dalam } \\
\text { kejadian yang paling banyak } \\
\text { terjadi }\end{array}$ & $\begin{array}{l}\text { Lebih dari } 1 \text { kali per tahun } \\
\text { sampai dengan } 1 \text { kali per bulan }\end{array}$ \\
\hline 5 & Hampir pasti & $\begin{array}{l}\text { Sering terjadi diharapkan } \\
\text { muncul dalam keadaan yang } \\
\text { paling banyak terjadi }\end{array}$ & Lebih dari 1 kali perbulan \\
\hline
\end{tabular}

(Sumber : [23]) 
Tabel 3 Kriteria Consequences

\begin{tabular}{|l|l|l|l|}
\hline Level & Uraian & Keparahan Cedera & Hari Kerja \\
\hline 1 & $\begin{array}{l}\text { Tidak } \\
\text { signifikan }\end{array}$ & $\begin{array}{l}\text { Kejadian tidak menimbulkan } \\
\text { kerugian atau cedera pada } \\
\text { manusia }\end{array}$ & $\begin{array}{l}\text { Tidak menyebabkan kehilangan } \\
\text { hari kerja }\end{array}$ \\
\hline 2 & Kecil & $\begin{array}{l}\text { Menimbulkan cedera ringan } \\
\text { kerugian kecil dan tidak } \\
\text { menimbulkan dampak serius } \\
\text { terhadap keberlangsungan } \\
\text { bisnis }\end{array}$ & $\begin{array}{l}\text { Masih dapat bekerja pada hari/ } \\
\text { shift yang sama }\end{array}$ \\
\hline
\end{tabular}

Sumber :[23])

Tabel 4 Kriteria Consequences (lanjutan)

\begin{tabular}{|l|l|l|l|}
\hline Level & Uraian & Keparahan Cedera & Hari Kerja \\
\hline 3 & Sedang & $\begin{array}{l}\text { Cedera berat dan dirawat di } \\
\text { rumah sakit, tidak } \\
\text { meniimbulkan cedera tetap, } \\
\text { kerugian finansial sedang }\end{array}$ & $\begin{array}{l}\text { Kehilangan hari kerja dibawah } \\
\text { 3 hari }\end{array}$ \\
\hline 4 & Berat & $\begin{array}{l}\text { Menimbulkan cedera parah } \\
\text { dan cacat tetap serta kerugian } \\
\text { finansial besar yang } \\
\text { menimbulkan dampak serius } \\
\text { terhadap keberlangsungan } \\
\text { usaha }\end{array}$ & $\begin{array}{l}\text { Kehilangan hari kerja 3 hari } \\
\text { atau lebih }\end{array}$ \\
\hline 5 & Bencana & $\begin{array}{l}\text { Mengakibatkan korban } \\
\text { meninggal dan kerugian parah. } \\
\text { Bahkan, dapat menghentikan } \\
\text { kegiatan usaha selamanya }\end{array}$ & $\begin{array}{l}\text { Kehilangan haru kerja } \\
\text { selamanya }\end{array}$ \\
\hline
\end{tabular}

(Sumber :[23])

Tabel 5 Risk Rating Number (RRN)

\begin{tabular}{|c|c|c|c|c|c|c|c|}
\hline \multicolumn{7}{|c|}{ Tingkat Bahaya } & Keterangan Risiko \\
\hline \multirow{5}{*}{$\begin{array}{c}\text { Likelihood } \\
\text { (kemungkinan) }\end{array}$} & 5 & 5 & 10 & 15 & 20 & 25 & \begin{tabular}{l|r} 
& Rendah
\end{tabular} \\
\hline & 4 & 4 & 8 & 12 & 16 & 20 & Sedang \\
\hline & 3 & 3 & 6 & 9 & 12 & 15 & Tinggi \\
\hline & 2 & 2 & 4 & 6 & 8 & 10 & Ekstrim \\
\hline & 1 & 1 & 2 & 3 & 4 & 8 & \\
\hline \multirow{2}{*}{\multicolumn{2}{|c|}{ Skala }} & 1 & 2 & 3 & 4 & 5 & \\
\hline & & \multicolumn{5}{|c|}{ Consequences } & \\
\hline \multicolumn{8}{|c|}{$\begin{array}{l}\text { Contoh Perhitungan : } \\
\text { Nilai Likelihood }=4 \\
\text { Nilai Consequences }=4 \\
\text { Hasil Risk Rating Number }(R R N)=\mathrm{L} \times \mathrm{C} \\
\text { Risk Rating Number }(R R N)=4 \times 4=16 \text { (terletak diwarna ungu yang artinya adalah } \\
\text { risiko ekstrim) }\end{array}$} \\
\hline
\end{tabular}

(Sumber :[23])

Pada tabel 4 Risk Rating Number (RRN), keterangan risiko diasumsikan sebagai berikut : 
1. Extreme risk adalah risiko ekstrim yang memerlukan penanggulangan segera atau penghentian kegiatan atau melibatkan manajemen puncak perusahaan untuk melakukan perbaikan segera mungkin [24], [25].

2. High risk adalah risiko tinggi yang memerlukan penjadwalan tindakan perbaikan secepatnya dan pelatihan oleh pihak perusahaan [26], [27].

3. Moderate adalah risiko menengah yang membutuhkan perhatian dan pengawasan dari pihak perusahaan [28], [29].

4. Low risk adalah risiko rendah (aman) dan tidak perlu dilakukan perhatian dan pengawasan dari pihak perusahaan terkait dengan risiko kecelakaan yang rendah [30],[31].

\section{Hasil dan Pembahasan}

Gas cleaning system berfungsi untuk membersihkan gas blast furnace yang merupakan hasil dari blast furnace plant. Setelah gas dibersihkan dengan tingkat efisiensi pembersihan hingga $80 \%$, semi clean gas akan masuk ke dalam scrubber untuk proses pembersihan gas berikutnya dan juga proses penurunan suhu gas dengan spray dari 10 water nozzle. Pada tahap berikutnya, clean blast furnace gas yang suhunya telah turun menjadi $43-48{ }^{\circ} \mathrm{C}$ dan tekanan $10-12.5 \mathrm{KPa}$ akan masuk ke demister untuk melalui proses dewatering system yaitu pengurangan dan pembersihan kadar air yang berada dalam clean blast furnace gas. Setelah selesai, clean gas blast furnace yang memiliki dust content sebesar $<5 \mathrm{mg} / \mathrm{Nm}^{3}$ dan water content sebesar $<7 \mathrm{mg} / \mathrm{Nm}^{3}$ akan masuk ke dalam gas holder pada plant general facility di blast furnace complex.

Setelah diketahui tentang fungsi dan penjelasan dari gas cleaning system, dilakukan pengolahan data tentang HAZOPs pada area cleaning system dengan hasil sebagai berikut:

Table 1 HAZOPs Area Gas Cleaning System

\begin{tabular}{|c|c|c|c|c|c|c|c|c|c|}
\hline \multirow[t]{2}{*}{ Node } & \multirow{2}{*}{$\begin{array}{l}\text { Guide } \\
\text { Word }\end{array}$} & \multirow[t]{2}{*}{ Deviation } & \multirow[t]{2}{*}{ Causes } & \multirow{2}{*}{$\begin{array}{c}\text { Consequen } \\
\text { ces }\end{array}$} & \multirow{2}{*}{$\begin{array}{c}\text { Safegua } \\
r d\end{array}$} & \multicolumn{3}{|c|}{ Risk Matrixs } & \multirow[t]{2}{*}{ Recommendation } \\
\hline & & & & & & $\mathrm{L}$ & $\mathrm{S}$ & $\begin{array}{c}\mathrm{RR} \\
\mathrm{N}\end{array}$ & \\
\hline $\begin{array}{l}\text { Upper } \\
\text { discharge } \\
\text { volve of } \\
\text { dust bin } 1 \\
\text { and } 2\end{array}$ & $\begin{array}{l}\text { Instrum } \\
\text { entation }\end{array}$ & $\begin{array}{l}\text { Part of } \\
\text { instrument } \\
\text { aion }\end{array}$ & $\begin{array}{l}\text { Terjadi } \\
\text { kesalah } \\
\text { an } \\
\text { sinyal } \\
\text { pengop } \\
\text { erasian }\end{array}$ & $\begin{array}{l}\text { Indikator } \\
\text { yang } \\
\text { diinfokan } \\
\text { mengalami } \\
\text { ketidakcoc } \\
\text { okan } \\
\text { antara } \\
\text { HMI dan } \\
\text { kondisi } \\
\text { aktual } \\
\text { lapangan }\end{array}$ & $\begin{array}{l}\text { Visual } \\
\text { inspecti } \\
\text { on }\end{array}$ & 2 & 2 & $\mathrm{~L}$ & $\begin{array}{l}\text { Tidak perlu } \\
\text { rekomendasi } \\
\text { karena Risk } \\
\text { Matrix pada level } \\
\text { Low }\end{array}$ \\
\hline $\begin{array}{l}\text { Lower } \\
\text { discharge } \\
\text { volve of } \\
\text { dust bin } 1 \\
\text { dan } 2\end{array}$ & $\begin{array}{l}\text { Functio } \\
\text { nability }\end{array}$ & $\begin{array}{l}\text { Part of } \\
\text { functionali } \\
\text { ty }\end{array}$ & $\begin{array}{l}\text { Terjadi } \\
\text { kegagal } \\
\text { an } \\
\text { pengop } \\
\text { erasioa } \\
\text { n }\end{array}$ & $\begin{array}{l}\text { Memungki } \\
\text { nkan } \\
\text { terjadinya } \\
\text { pengeluara } \\
\text { n blast } \\
\text { furnace } \\
\text { gas ke area } \\
\text { sekitar } \\
\text { plant yang }\end{array}$ & Alarm & 3 & 4 & $\mathrm{H}$ & $\begin{array}{l}\text { Melakukan } \\
\text { perawatan pada } \\
\text { alat }\end{array}$ \\
\hline
\end{tabular}




\begin{tabular}{|c|c|c|c|c|c|c|c|c|c|}
\hline & & & & $\begin{array}{l}\text { bisa } \\
\text { terhirup } \\
\text { operator } \\
\text { sehingga } \\
\text { menimbul } \\
\text { kan } \\
\text { kecelakaan } \\
\text { kerja }\end{array}$ & & & & & \\
\hline $\begin{array}{l}\text { Blast } \\
\text { furnace } \\
\text { gas pipe }\end{array}$ & $\begin{array}{l}\text { Pressur } \\
\mathrm{e}\end{array}$ & $\begin{array}{l}\text { Less } \\
\text { pressure }\end{array}$ & $\begin{array}{l}\text { Terjadi } \\
\text { kebocor } \\
\text { an pada } \\
\text { titik - } \\
\text { titik } \\
\text { flange } \\
\text { dan } \\
\text { sepanja } \\
\text { ng jalur } \\
\text { pipa }\end{array}$ & $\begin{array}{l}\text { Penurunan } \\
\text { tekanan } \\
\text { dalam pipa } \\
\text { blast } \\
\text { furnace } \\
\text { gas, } \\
\text { operator } \\
\text { beresiko } \\
\text { menghirup } \\
\text { blast } \\
\text { furnace } \\
\text { gas } \\
\text { sehingga } \\
\text { mengakiba } \\
\text { tkan } \\
\text { kecelakaan } \\
\text { kerja }\end{array}$ & $\begin{array}{l}\text { Visual } \\
\text { insoecti } \\
\text { on } \\
\text { dengan } \\
\text { memba } \\
\text { wa CO } \\
\text { detector }\end{array}$ & 3 & 3 & $\mathrm{H}$ & $\begin{array}{l}\text { Melakukan } \\
\text { tindakan } \\
\text { perbaikan pada } \\
\text { pipa yang bocor } \\
\text { dengan } \\
\text { didampingi } \\
\text { petugas safety }\end{array}$ \\
\hline $\begin{array}{l}\text { Supply } \\
\text { water pipe } \\
\text { to spray } 4- \\
10\end{array}$ & Less & $\begin{array}{l}\text { Less } \\
\text { pressure }\end{array}$ & $\begin{array}{l}\text { Terjadi } \\
\text { kebocor } \\
\text { an pada } \\
\text { pipa }\end{array}$ & $\begin{array}{l}\text { Pengurang } \\
\text { an } \\
\text { efektivitas } \\
\text { penurunan } \\
\text { suhu dan } \\
\text { pembersih } \\
\text { an blast } \\
\text { furnace } \\
\text { gas }\end{array}$ & $\begin{array}{l}\text { Visual } \\
\text { inspecti } \\
\text { on }\end{array}$ & 3 & 2 & $\mathrm{M}$ & $\begin{array}{l}\text { Melakukan } \\
\text { perbaikan pada } \\
\text { titik kebocoran } \\
\text { pipa }\end{array}$ \\
\hline $\begin{array}{l}\text { Recirculati } \\
\text { on pump } 1 \\
\text { dan } 2\end{array}$ & $\begin{array}{l}\text { Functio } \\
\text { nality }\end{array}$ & $\begin{array}{l}\text { Part of } \\
\text { functionali } \\
\text { ty }\end{array}$ & $\begin{array}{l}\text { Kegaga } \\
\text { lan } \\
\text { pengop } \\
\text { erasian } \\
\text { recircul } \\
\text { ation } \\
\text { pump }\end{array}$ & $\begin{array}{l}\text { Pemenuha } \\
\mathrm{n} \text { level air } \\
\text { pada chute } \\
1 \text { dan } \\
\text { chute yang } \\
\text { bisa } \\
\text { menutup } \\
\text { jalur gas } \\
\text { dan } \\
\text { menghenti } \\
\text { kan proses } \\
\text { operasi } \\
\text { blast } \\
\text { furnace }\end{array}$ & $\begin{array}{l}\text { Visual } \\
\text { inspecti } \\
\text { on }\end{array}$ & 4 & 2 & $\mathrm{H}$ & $\begin{array}{l}\text { Selalu melakukan } \\
\text { pendataan rutin } \\
\text { mengenai } \\
\text { getaran, suara, } \\
\text { suhu motor dan } \\
\text { suhu pompa } \\
\text { untuk } \\
\text { menghindari } \\
\text { kegagalan } \\
\text { pengoperasian } \\
\text { pompa }\end{array}$ \\
\hline
\end{tabular}




\begin{tabular}{|c|c|c|c|c|c|c|c|c|c|}
\hline $\begin{array}{l}\text { Electric } \\
\text { regulating } \\
\text { Valve } \\
\text { 00GNK01 } \\
\text { AA201 }\end{array}$ & $\begin{array}{l}\text { Instrum } \\
\text { ention }\end{array}$ & $\begin{array}{l}\text { Part of } \\
\text { instrument }\end{array}$ & $\begin{array}{l}\text { Pengka } \\
\text { ratan } \\
\text { pada } \\
\text { ulir } \\
\text { valve } \\
\text { sehingg } \\
\text { a } \\
\text { mengal } \\
\text { ami } \\
\text { kemace } \\
\text { tan } \\
\text { pergera } \\
\text { kan } \\
\text { saat } \\
\text { diopera } \\
\text { sikan }\end{array}$ & $\begin{array}{l}\text { Indikasi } \\
\text { sensor } \\
\text { yang } \\
\text { diinfokan } \\
\text { mengalami } \\
\text { ketidakcoc } \\
\text { okan } \\
\text { antara } \\
\text { HMI dan } \\
\text { kondisi } \\
\text { aktual } \\
\text { lapangan }\end{array}$ & Alarm & 3 & 1 & $\mathrm{~L}$ & $\begin{array}{l}\text { Tidak perlu } \\
\text { rekomendasi } \\
\text { karena Risk } \\
\text { Matrix pada level } \\
\text { low }\end{array}$ \\
\hline
\end{tabular}

(Sumber : Olah Data)

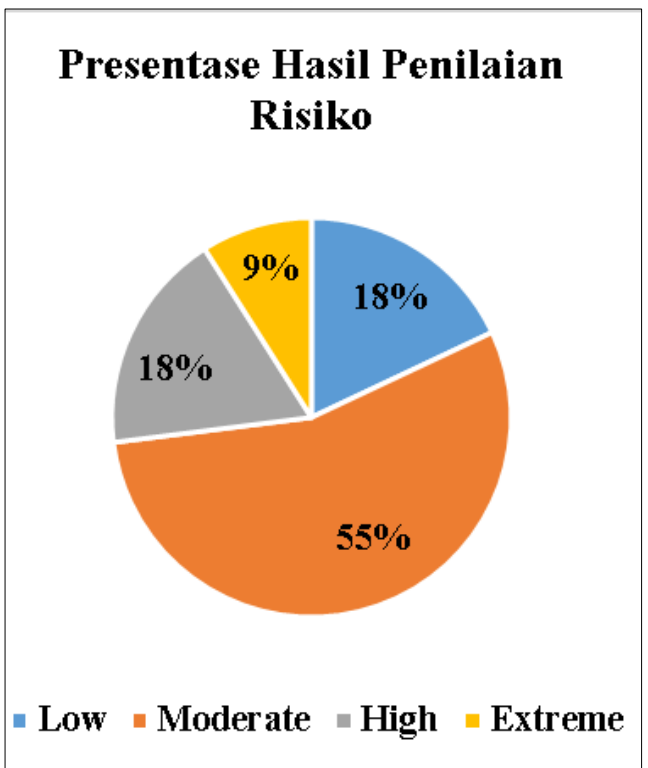

Gambar 2 Penyimpangan Risiko dari Hasil HAZOPs

Berdasarkan Tabel 5 dan Gambar 2 di atas, terdapat sepuluh komponen (parameter) pada area gas cleaning system dan didapatkan juga bahwa 11 penyimpangan yang kemungkinan terjadi dari semua node yang ada yaitu untuk level risiko extreme sebanyak 1 (satu) penyimpangan atau sebesar 9\%, level risiko high risk sebanyak 2 (dua) penyimpangan atau sebesar $18 \%$, level risiko moderate sebanyak 6 (enam) penyimpangan atau sebesar 55\% dan level risiko low risk sebanyak 2 (dua) penyimpangan atau sebesar 18\%. Pada nilai extreme risk didapatkan pada komponen lower discharge valve of dust bin 1 dan 2 dengan deviation part of functionability.

\section{Kesimpulan dan Saran}

Berdasarkan penelitian yang sudah dilakukan pengolahan dan pembahasan, dapat disimpulkan dengan beberapa kesimpulan sebagai berikut : 
1. Hasil identifikasi terdapat 10 (sepuluh) komponen (parameter) pada area gas cleaning system dan didapatkan 11 (sebelas) risiko penyimpangan yang bisa terjadi. Nilai risiko dengan perincian untuk level risiko extreme sebanyak 1 (satu) penyimpangan atau sebesar $9 \%$, level risiko high risk sebanyak 2 (dua) penyimpangan atau sebesar $18 \%$, level risiko moderate sebanyak 6 (enam) penyimpangan atau sebesar 55\% dan level risiko low risk sebanyak 2 (dua) penyimpangan atau sebesar $18 \%$.

2. Pada nilai extreme risk didapatkan pada komponen lower discharge valve of dust bin 1 dan 2 dengan deviation part of functionability.

3. Rekomendasi untuk pencegahan dan penanganan deviation part of functionability yang diakibatkan oleh kegagalan pengoperasian bisa dilakukan dengan cara perawatan secara periodik, memperbaiki hose hidrolik yang rusak dan jika memungkinkan dilakukan penggantian gasket serta pemasangan ulang valve untuk mendapatkan posisi ketegangan hose yang baik.

\section{Daftar Pustaka}

[1] S. Ramli, Pedoman Praktis Manajemen Risiko dalam Prespektif K3 OHS Risk Management. Jakarta: Dian Rkyat, 2010.

[2] E. Acar et al., "Development of Stitched, Braided and Woven Composite Structures in the ACT Program and at Langley Research Center (1985 to 1997)," J. Aircr., 2011, doi: DOI: 10.1016/j.cie.2009.11.005.

[3] J. Min, Y. Kim, S. Lee, T.-W. Jang, I. Kim, and J. Song, "The Fourth Industrial Revolution and Its Impact on Occupational Health and Safety, Worker's Compensation and Labor Conditions," Saf. Health Work, Sep. 2019, doi: 10.1016/J.SHAW.2019.09.005.

[4] A. Musyafa and H. Adiyagsa, "Hazard and Operability study in Boiler System of The Steam Power Plant," Int. J. Sci. Technol. (IJSTE), vol. 1, no. 3, pp. 1-10, 2012.

[5] K. Amponsah-Tawiah and J. Mensah, "Occupational Health and Safety and Organizational Commitment: Evidence from the Ghanaian Mining Industry," Saf. Health Work, vol. 7, no. 3, pp. 225-230, 2016, doi: 10.1016/j.shaw.2016.01.002.

[6] N. Hoboubi, A. Choobineh, F. Kamari Ghanavati, S. Keshavarzi, and A. Akbar Hosseini, "The Impact of Job Stress and Job Satisfaction on Workforce Productivity in an Iranian Petrochemical Industry," Saf. Health Work, vol. 8, no. 1, pp. 67-71, 2017, doi: 10.1016/j.shaw.2016.07.002.

[7] D. E. Gregory and S. E. Romero, "Can the use of an alternatively designed tamper alter spine posture and risk of upper limb injury while tamping espresso?," Int. J. Ind. Ergon., vol. 65, pp. 103-109, 2018, doi: 10.1016/j.ergon.2017.07.008.

[8] V. Golchha, P. Sharma, J. Wadhwa, D. Yadav, and R. Paul, "Ergonomic risk factors and their association with musculoskeletal disorders among Indian dentist: A preliminary study using Rapid Upper Limb Assessment," Indian J. Dent. Res., 2015, doi: 10.4103/0970-9290.152202.

[9] E. Jamilah, Y. H. Yadi, and A. Umyati, "Identifikasi Potensi Bahaya Dengan Metode Hazard And Operability Study ( HAZOP ) Di Area Boiler PT . XYZ," J. Tek. Ind. Univ. Ageng Tirtayas, 2013.

[10] N. Eizenberg, S., Shacham, M., Brauner, "Combining HAZOP with dynamic simulation Applications for safety education. Journal of Loss Prevention in the Process Industries," J. Loss Prev. Process Ind., vol. 9, pp. 754-761, 2006.

[11] C. A. Ericson, "Hazard Analysis Techniques for System Safety." p. 1, 2015. 
[12] F. C. B. Tyler, HAZOP: Guide to Best Practic, 3rd ed. Elsevier, 2015.

[13] L. Allford and R. Gowland, "Foreword," HAZOP Guid. to Best Pract., pp. ix-xi, 2015, doi: 10.1016/b978-0-323-39460-4.00017-7.

[14] C. Atombo, C. Wu, E. O. Tettehfio, G. Y. Nyamuame, and A. A. Agbo, "Safety and Health Perceptions in Work-related Transport Activities in Ghanaian Industries," Saf. Health Work, vol. 8, no. 2, pp. 175-182, 2017, doi: 10.1016/j.shaw.2016.10.002.

[15] AustralianStandard, "Australian Standard / New Zaeland Standard Risk Management 4360:2004." Sydney and Wellington, New Zealand, p. 1, 2004.

[16] et al. Cagno, E., F. Caron, Risk analysis in plant commissioning: the Multilevel Hazop." Reliability Engineering \& System Safety. 2002.

[17] et al Dunjó, J., V. Fthenakis, "Hazard and Operability (HAZOP) Analysis." p. 1, 2010.

[18] G. H. Choi, "Effectiveness of Direct Safety Regulations on Manufacturers and Users of Industrial Machines: Its Implications on Industrial Safety Policies in Republic of Korea," Saf. Health Work, vol. 8, no. 1, pp. 59-66, 2017, doi: 10.1016/j.shaw.2016.09.005.

[19] S. O. D. Ningsih and S. W. Hati, "ANALISIS RESIKO KESELAMATAN DAN KESEHATAN KERJA (K3) DENGAN MENGGUNAKAN METODE HAZARD AND OPERABILITY STUDY (HAZOP) PADA BAGIAN HYDROTEST MANUAL DI PT. CLADTEK BI METAL MANUFACTURING,” J. Appl. Bus. Adm., 2019, doi: 10.30871/jaba.v3i1.1288.

[20] W. Agus, “Analisis Kesehatan dan Keselamatan Kerja Dengan Metode Hazard And Operability (Hazop) Di Bengkel Dan Laboratorium Teknik Instalasi Tenaga Listrik SMK N 2 Wonosari 2017," Pendidik. Tek. Elektro Fak. Tek. Univ. Negeri Yogyakarta 2017, 2017.

[21] S. Rahayuningsih and J. A. Pradana, "Identifikasi Penerapan Dan Pemahaman Kesehatan Dan Keselamatan Kerja Dengan Metode Hazard And Operability Study (Hazop) Pada UMKM Eka Jaya," JATI UNIK J. Ilm. Tek. dan Manaj. Ind., vol. 2, no. 1, p. 20, 2019, doi: 10.30737/jatiunik.v2i1.274.

[22] Baradit Georgy, "A New Software-Based HAZOP Study Development Metodelogy." Departement of Process Enginering, University of Pannonia, Hungaria, p. 1, 2007.

[23] D. Retnowati, “Analisa Risiko K3 Dengan Pendekatan Hazard and Operability Study (Hazop)," Tek. Eng. Sains J., vol. 1, no. 1, pp. 41-46, 2017, doi: 10.5281/zenodo.1115999.

[24] O. E. Williamson et al., "CAPACIDADES DINÂMICAS COMO DIFERENCIAL ESTRATÉGICO PARA A SUSTENTABILIDADE,” J. Bus. Res., 2016, doi: 10.1016/j.technovation.2012.01.004.

[25] P. Paiton, P. T. Ytl, L. Kristianingsih, and A. S. Proses, "Analisis Safety System dan Manajemen Risiko pada Steam Boiler PLTU di Unit 5," J. Tek. POMITS, 2013.

[26] B. Pierre, J. Mathieu, G. Alexandre, and N. Anne-Sophie, "Fatigue-related risk perception among emergency physicians working extended shifts," Appl. Ergon., vol. 82, no. November 2018, p. 102914, 2020, doi: 10.1016/j.apergo.2019.102914.

[27] D. Macdonald, Practical Hazops, Trips and Alarms, 1st ed. Newnes, 2004.

[28] L. N. Wati, "Manajemen Risiko Bisnis," Ekon. Bisnis dan Manaj., vol. I, no. September, pp. 255-267, 2012.

[29] A. Wijaya, T. W. Panjaitan, and H. C. Palit, "Healty and Safety Management System," 1998. .

[30] E. Mas'idah, W. Fatmawati, and L. Ajibta, "Analisa Manual Material Handling $(\mathrm{MMH})$ dengan Menggunakan Metode Biomekanika Untuk Mengidentifikasi Resiko 
Cidera Tulang Belakang (Musculoskeletal Disorder)," Univ. Sultan Agung, vol. 45, no. 119, pp. 37-56, 2009, doi: 10.1016/j.gde.2004.09.003.

[31] P. Baybutt, "A critique of the Hazard and Operability (HAZOP) study," J. Loss Prev. Process Ind., 2015, doi: 10.1016/j.jlp.2014.11.010. 